\title{
TNI Accelerative Communication in Mitigation the Citarum River Environment in West Java
}

\author{
Ahmad Mulyana ${ }^{1}$, Selamat Ginting ${ }^{2}$ \\ \{ahmadmulyana@mercubuana.ac.id ${ }^{1}$, selamatginting@gmail.com $\left.{ }^{2}\right\}$ \\ Universitas Mercu Buana, Jakarta, Indonesia ${ }^{12}$
}

\begin{abstract}
This research examines Indonesian Military Forces (Tentara Nasional Indonesia (TNI)) accelerative communication in mitigation to the Citarum River environment in West Java. Citarum is initially called by the World Ban as the dirtiest river in the world. [1]. Now, some sections of the Citarum area are tourism destinations. Such condition exists by TNI's contribution as the leading guard for the Citarum Harum national project. They have successfully involved the society to participate in building environmental-friendly behaviors in the Citarum area. The research focus is how the TNI's social communication in the Citarum Harum program to apply accelerative communication principles, based on development social communication. This research is generally aimed at obtaining description on the communication approach conducted by the TNI to achieve the Citarum Harum program's goal. Whereas theories and concepts applied to this research include organizational communication theory, development social communication, accelerative communication, and environmental mitigation concept, especially for river. Method applied to this research is case study. Case study is classified as descriptive analysis research. It is a kind of research focusing on specific case for observation and analysis in precise and thorough way. The research is conducted in intensive, detailed, and deep way against specific organization, institution, and symptom with narrow area or object. Data is collected through observation and depth interview with source persons, namely members of TNI running activities for Citarum Harum in Bandung and its surrounding area. The research results describe that accelerative communication is developed based on group interpersonal communication competence as a basis for building public participation for achieving Citarum Harum.
\end{abstract}

Keywords: Communication, Accelerative, TNI, Mitigation, Citarum River

\section{Introduction}

Citarum River's condition got international attention as the dirtiest river in the world [1]. It is a sarcasm by international public to the pride river of West Java's people. Other than river damages, in fact, some damages occur to the upstream of Citarum. Serious problem faced by West Java, Jakarta Special Region is the loss of Citarum spring. It also includes damaged forest around Mount Wayang, upstream area of Citarum. If the society does not care about it and won't handle it, humanity disaster will happen. It includes damaged ecosystem to all creatures living around Citarum River area. It will be civilization disaster in the middle of Sundanese people living in West Java and Jakarta. 
By integrated efforts made by West Java Provincial Government, Military Regional Command (Kodam) III/Siliwangi, and the society, Citarum River's environment is getting better for its cleanliness. Moreover, some areas even become tourism destinations. The Commander of Kodam III/Siliwangi Major General Doni Monardo, in the end of 2017 mobilized soldiers to clean Citarum River and to make Mount Wayang green area, upstream of Citarum area [2], [3]. Research special objectives and urgencies: To define TNI's accelerative communication model in environmental mitigation of Citarum Harum program; To disclose communication approach conducted by TNI so that Citarum Harum program's objectives are achieved; To disclose communication cooperation conducted by TNI and mass media for the program.

Scientific researchers specifically examined communication by Indonesian Army (TNI AD) with program to preserve environmental preservation is still not found. It includes Citarum Harum program initiated by TNI. In fact, there are some previous researches on the relation between civil and military from communication science perspective. However, they had by different case studies, either in Indonesian and a number of countries. Among others: [4], [5], [6], [7]. There were some applied theories and concepts. Organizational Theory. Vision and mission as organizational foundation sometimes contain objectives of the organization. Gibson says that organization is a unit coordinated and consists of at least two persons or more functioning to reach collective goals or a series of collective goals [8]. [9] Describes some characteristics of organization including among others 1) A social entity; 2) Goal directed 3) Intentionally structured activities, and; 4) clear limits.

Development and social communication theory. Discusses any efforts, methods, and techniques to deliver concept and skills on development coming from development initiator to the target society. It is aimed at being able to comprehend, to receive, and to participate in development. Development as a process of participatory social changes in wide term for improving social condition and existence (including high justice, freedom, and quality assessed as high) for major society through their achievement on higher control against environment [10].

Public policy theory. Implementation of public policies is an activity of public policy process defining whether the policy contacts with public interests and publicly accepted. George Edwards III Model [11] says "In our approach to the study of policy implementation, we begin in the abstract and ask: What are the preconditions for successful policy implementation?" to consider four factors of public policy implementation, namely as follows: "Communication, resources, disposition or attitudes, and bureaucratic structure". The four implementation factors are considered crucial by each implementor to run public policies. The four factors interact each other, meaning that when one factors is absent, the other three factors will be influenced and they will cause weak implementation of public policies.

Interpersonal communication is a way to support individuals collectively through sustainable learning. Politely interpersonal communication competence will effectively interact among members of society internally and externally. It becomes a strength for required social network formation. By developing interpersonal communication potential, other than social network. Social capital formation as basis for collective commitment on society development. By interpersonal communication, it is expected that any potentials found in society can be developed according to related capacity for obtaining maximum results. Moreover, each individual may form a learning group providing with development opportunity on hopes, aspirations, and motivations for changing old life style towards new life style. 
Mitigation Concept. Disaster mitigation is a crucial step as a point of departure for disaster management. There are four significant factors on disaster mitigation as follows [12]: Information and map of areas vulnerable to disasters for any disaster type; Spread of information to improvement public understanding and awareness to face disasters since they live in any area vulnerable to disasters; Defining what needs to do and to avoid, as well as finding the way to rescue if any disaster occurs, and Management and arrangement of areas vulnerable to disasters for reducing disaster threat.

\section{Research Method}

The research will describe TNI's development social communication model to realize a society that is aware of environmental preservation along Citarum River. Whereas theories and concepts applied to this research include organizational communication theory, development social communication, accelerative communication, and environmental mitigation concept, especially for river. Method applied to this research is case study. Case study is classified as descriptive analysis research. It is a kind of research focusing on specific case for observation and analysis in precise and thorough way. The research is conducted in intensive, detailed, and deep way against specific organization, institution, and symptom with narrow area or object.

Data is collected through observation and depth interview with source persons, namely members of TNI running activities for Citarum Harum in Bandung and its surrounding area. The event is actual, happening, specific, priority, and unique. It is unique since the leading party is military. Citarum program will be implemented until 2024-2025 and become national project and international interest. The researcher did not only comprehend the case from outside, but also from inside as a complete and detailed entity. Its data collection technique is by dept interview, documentation, and direct observation in complementary way.

\section{Results and Discussion}

Scientific studies specifically examining the TNI's accelerative communication model with the environmental sustainability recovery program have not been found much. Including case studies such as the Citarum Harum Program initiated by the TNI. Indeed, there have been several previous studies on civilian and military relations or relations from various perspectives of the social sciences. However, with different case studies, both in Indonesia and a number of countries.

Several previous studies, including: [7] Charles D Allen from US Army War College The focus of the study is to discuss the behaviour of military officers and review its impact when changing to leadership when considering civilians. As a result, for the Army, military civilian relations are an important part of the curriculum that military schools have to. [13] Carnes Lord from US Naval War College. The focus of his study, professionalism has become the focus of attention of military leaders through their special missions, traditions and practices. As a result, military leaders began to pay attention to and improve communication patterns as part of military professionalism. 
[14] William E Rapp of the US Army War College. As a result, only by working together and overcoming boundaries will both military and civilian need a strong dialogue in the national interest. [15] Khadga KC from the Central Department of Political Science, Tribhuwan University. As a result, the military began to affirm democratic values. Predictions in the future there will be fundamental changes in terms of military organization involving several parties, increased professionalism, increased accountability, transparency and loyalty from civilian authorities. [16] Peter Feafer from the Department of Political Science, Duke University, Durham, NC, USA. As a result, each study is very likely to offer new insights on a lasting problem of civil-military relations and how to make the military an effective defender of the state without making the military a threat to the state. [17] Ejaz Hussain from Iqra University. As a result, structural dynamics influenced politics and the military in Pakistan. The military, part of the praetorian oligarchy, emerged as a strong political actor, because of its coercive power.

[18] Victor Jacob Lucas Lopulalan et al from. Défense University. As a result, efforts to increase social communication skills must be carried out by using appropriate methods to detect and prevent acts of terrorism. Equipment and supplies are needed in the form of Puskodalops, which includes a Cybernet, communication tools and internet networks that can help process information and technology related to terrorism. Acknowledged involvement of TNI for the success of Citarum Harum is said by West Java Governor, Ridwan Kamil. "Citarum Harum program will not be successful if the TNI was not involved. I personally witnessed that Citarum riverside was occupied by illegal houses and public activities were not well managed," Ridwan said.

Humanist approach by TNI, said Ridwan, was capable to change such condition to be neat and friendly environment. It is the same with naughty industries those started being reluctant when the TNI dropped its hand over there [19]. Citarum Harum Program's achievement from cleanliness side reached around 40\% [20]. (Moreover, some areas around Citarum River become tourism destinations. Before TNI was involved, Citarum River is an unfinished home work. Water and environment around its streams have been polluted for tens of years.

By virtue of President Regulation Number 15 of 2018 on the Acceleration of Pollution Control and Local Damages to Citarum River Stream Area as signed on March 14, 2018, TNI-AD (Army) is involved to realize it. Execution of the program was led by the Commander of Task Force, namely West Java Governor. Vice commanders include, among others, the Commander of Kodam III/Siliwangi. It means that the army is directly involved in the execution. 1,700 TNI personnel were deployed to guard and to look after Citarum River that is divided into 22 sectors and one sector for nursery.

As said by West Java Governor, the success of TNI to realize acceleration of Citarum River through humanist approach, not repressive one. TNI made communication to activate the society so that they will participate in environmental mitigation to make the river clean. TNI made communication to the society by personal and group methods. Interpersonal communication functions to create pleasant climate. Describing work atmosphere of the communication that was capable to create harmonized relationship among individuals. Communicator as strong and determined soldier with sensitive and responsive to any fluctuation and phenomena occurred in the society around Citarum. TI is capable to conduct effective and open communication. Finally, it can build respectively individual awareness. 
Such a condition can create capability and improve balanced, equal, and useful social empowerment for stakeholders.

Public empowerment can maximize benefit value to the highest one for society. Interpersonal communication effectiveness is highly important to improve participation in empowerment. Without good participation, empowerment will be really hard and even impossible to reach success in according to any defined goal. It confirms the statement of GR Terry in Nanang Fattah [21], requirements for a leader, other than other competence, also include communication skills. It includes interpersonal communication. In fact, public empowerment can't be separated from interpersonal communication. This kind of communication has basic role and task to motivate society for taking more discipline action while working.

Other strategies possible to develop through interpersonal communication in public empowerment are as follows: (a) Rationally empiric strategy, (b) Strategies for changing old life style to new life style, and (c) Strategy to follow direction of changes that possible to improve welfare. In context of social worker for public empowerment strategy, three ways can be applied as follows: (a) Client empowerment individually through counselling guide aiming at guiding or training duty implementation, (b) empowerment to group of society aiming at improving awareness, knowledge, skills, and behaviours of society so that they will have problem solving skills, (c) Empowerment by high-scale empowerment to make client has competence for understanding changes in wider environmental system. The author summarizes the discussion of accelerated communication carried out by the TNI in mitigating the environment of the Citarum River into seven important points.

First; Socialization. Direct socialization and education were carried out in sub-districts, villages, mosques, schools, public facilities and community housing by resource persons and members of the integrated task force on the importance of maintaining the environment and cleanliness around the Citarum river in order to change people's thinking while maintaining high local wisdom and culture as well as local community customs; Appeals through the installation of banners at points prone to rivers and villages containing an appeal not to dispose of garbage, factory waste and household waste; and Socialization activities are carried out simultaneously, at any time and every opportunity because the task force mingles with the community. Second; Greening. Carrying out reforestation along the Citarum watershed (DAS), requiring tens of thousands of trees; Trees planted include: flamboyant trees, soursop trees, rambutan trees, jackfruit trees, guava trees, mango trees, avocado trees, durian trees, mahogany trees, suran trees, coffee, cinnamon, eucalyptus and katapang trees.

Third; Domestic Waste Management. Carry out training and assistance in household waste processing for community welfare; Making trash cans, trash bins, in RT and RW in each subsector according to the agreement of the residents; Construction of landfills (TPS), production of bio pores and waste sorting machines at each confluence of tributaries and the Citarum River as well as at critical points of waste accumulation; Manufacture of a waste incinerator; Operate heavy equipment for collecting garbage during the rainy season; and Operationalize sampat transport fleets (garbage trucks, garbage carts and tricycles). Fourth; Surface Garbage Removal. Carry out removal of surface rubbish and sedimentation on river banks at critical points along the Citarum watershed; and arrangement of river banks as recreational areas such as jogging tracks, recreational parks and so on. 
Fifth; Control and Supervision. Installation of CCTV at several points prone to dumping waste and TPS; CCTV installation in industrial waste disposal areas and at other vulnerable points along the Citarum watershed; and Monitoring is carried out at the Posko and can be accessed 24 hours by Citizen Journalism regarding data or developments in the latest situation. Sixth; Law enforcement. Carry out patrols and surveillance along the Citarum watershed; Investigate any indication of river pollution; Carry out an integrated investigation with the Police and the Environmental Service; and Summons's business actors who dispose of waste in the Citarum river. Seventh; Prevention of Industrial Waste Pollution. Carry out outreach to business actors not to pollute the environment and carry out industrial waste processing; Involving DLHK, police, head of sub-district, village head, RT, RW and community leaders around the factory; and Erecting Swapantau Post buildings at two tributary meeting points to monitor illegal waste disposal activities.

Accelerative communication conducted by communicating while giving real behaviours or actions. Such communication was conducted by staying at people's houses in a number of villages, sleeping and doing activities in village halls, visiting schools, markets, and factories. It includes giving messages in traditional events or religious ones while making speeches. Making efforts to find any problems and wishes of the people living around Citarum River. Finding proper solution, with some innovations and aids by volunteers and any parties care about environment.

Therefore, accelerative communication conducted by TNI is a development and implementation of interpersonal communication capable to change cognition properly. Whereas its effectiveness was due to considering the following communication forms: (1) Openness; (2) Empathy; (3) Support; (4) Positive feeling; (5) Equality. It also confirms Wright's statement that such communication brings benefits: intimacy, flexibility, direct relationship, respect each other, and reaching objectives without persuading.

\section{Conclusions}

Based on above description, it can be defined that accelerative communication by TNI in Citarum Harum program is a process of communication. Message is delivered through personal communication competence that may change behaviors of people living around Citarum River. TNI has successfully applied its personal competence. Communication skill can generate high contribution to organizational performance in providing with services either internal and external ones. Such communication may influence active public participation in environmental mitigation to Citarum river.

From the description above, it can be defined here that the TNI's accelerative communication in the activity of creating the objectives of the Harum Citarum is a communication process where messages are conveyed through personal communication competencies supported by the credibility of the military figure through the typical verbal language of commandos and military uniforms which are a strong driving factor compared to if carried out by civilians. This competence can change the attitude of the people around the Citarum River quickly. The TNI army has succeeded in applying its personal competence in military packages. Communication skills supported by military credibility are able to make a high contribution to organizational performance in providing services, both internally and 
externally. Communication is able to influence the community to actively participate in mitigating the environment of the Citarum river

\section{References}

[1] J. I. Hamid, Kembalikan Citarum Harum, Jakarta: Lensa Indonesia.Com, 2018.

[2] M. TNI, Petunjuk Induk Tentang Teritorial TNI, .Nomor Perpang: 111/VIII/2011, Jakarta, 2011.

[3] M. TNI, Petunjuk Pelaksanaan Tentang Pembinaan Teritorial TNI, Jakarta: Peraturan Panglima TNI, 2011.

[4] K. Kardi, "Demokrasi Relasi Sipil-Militer pada era reformasi di Indonesia," Jurnal Sosiologi Pusat Kajian Sosiologi FISIP UI, pp. VOL 19, No.2,231-256, 2014.

[5] S. Aisyah, "Pasang Surut Hubungan Sipil-Militer dalam perpolitikan Pakistan Universitas Mulawarman," Jurnal Politik Provitile, p. Vol 1: 1, 2013.

[6] A. S. Soesilo, "Jaringan Purnawirawan Tentara Nasional Indonesia dalam Politik Relasi SipilMiliter Pasca Reformasi TNIPusat Kajian Sosiologi, Lab Sosio FISIP-UI," Sosiologi Masyarakat, pp. Vol 19, No.2, 2014.

[7] Allen, Charles D, "Civil-Military Relations in Transsitions.," JFQ 86, vol. 3 rd Quarter 2017, 2017.

[8] J. L. Gibson, Organisasi, Perilaku, Struktur dan Proses, Jakarta: Erlangga, 2000.

[9] A. A. Wahab, Anatomi Organisasi dan Kepemimpinan Pendidikan, Bandung: Alfabeta, 2008.

[10] E. R. d. F. Shoemaker, "Communication of Innovations: A Cross Cultural Approach," New York, The Free Press, 1987.

[11] G. C. E. III, Implementing Public Policy, Washington DC: Congressional Quarterly Press, 1980.

[12] P. Presiden, "Penyelenggaraan Penanggulangan Bencana," Jakarta, 2008.

[13] C. Lord, "On Military Professionalism and Civilian Control," JFQ 78, vol. 3 rd Quarter 2015, 2015.

[14] W. E. Rapp, "Ensuring Effective Military Voice," Parameters 46, Vols. (4) Winter 2016-2017, 2017.

[15] K. KC, " Civil-Military Relations in Nepal," Global \& Strategis, Vols. Th 8, No.1. January-June 2014, 2014.

[16] P. Feafer, "Civil-Military Relations and Policy: A Side of a New Wave of Scholarships," The Journal of Stretegic Studies, vol. 2016, 2016.

[17] E. Hussain, "Pakistan: Civil-Military Relations in a Post-Colonial State.," Ejaz Hussain from Iqra UnPCD Journal, Vols. IV, No.1. 2012, 2012.

[18] V. J. L. L. e. al, " Application of Social Communication (Komsos) in Detecting and Preventing Terrorism Actions in the Region of Kodim 0618 / BS Bandung City," Journal of Defense Management Study Program, vol. 3 No.3, 2017.

[19] Handri Handriansyah, "Air Sungai Citarum Sudah Bisa Diminum, Panglima TNI Sudah Mencobanya," Pikiran Rakyat, Bandung, 2020.

[20] LKBN Antara, "Panglima TNI Proses Pembersihan Sungai Citarum Sudah 40 Persen," Liputan6.com, Bandung, 2020.

[21] N. Fatah, "Landasan Manajemen Pendidikan," Remaja, Bandung, 2003.

[22] F. Azhari, "Ikhtilaf Ulama tentang Kedudukan Basmalah dalam Alfatihah Dibaca Ketika Shalat," 
Syariah: Jurnal Ilmu Hukum, vol. 15, no. 2, pp. 167-176, Desember 2015.

[23] A. I. Arifin, "Tindak Pidana Korupsi Menurut Hukum Pidana Islam," Lex et Societatis, vol. III, no. 1, pp. 72-82, Januari-Maret 2015.

[24] A. Fawaid, "Islam, Budaya Korupsi, dan Good Governance," Karsa, vol. XVII, no. 1, pp. 18-26, April 2010.

[25] M. B. Miles and A. M. Huberman, Analisis Data Kualitatif, Jakarta: UI Press, 1992.

[26] Pikiran-rakyat, "https://www.pikiran-rakyat.com/bandung-raya/pr-01319637/air-sungai-citarumsudah-bisa-diminum-panglima-tni-sudah-mencobanya?page=2," 15 Juli 2020.

[27] liputan6.com, "(https://www.liputan6.com/news/read/4068412/panglima-tni-proses-pembersihansungai-citarum-sudah-40-persen).," 15 Juli 2020.

[28] V. J. L. L. e. al, "Application of Social Communication (Komsos) in Detecting and Preventing Terrorism Actions in the Region of Kodim 0618 / BS Bandung City," Journal of Defense Management Study Program, , vol. 3 Number 3, 2017. 